\title{
Família e cuidado em narrativas de vida marcadas pela ausência paterna ${ }^{1}$
}

\section{Resumo}

Partindo de narrativas de vida de filhos sem o reconhecimento legal de paternidade, o objetivo deste artigo é analisar o cuidado e a reprodução da vida doméstica através do ponto de vista desses filhos sobre as mulheres que se responsabilizaram por eles quando crianças. Se, por um lado, essas narrativas falam sobre a falta de direitos, representada pela ausência paterna, de outro, elas trazem também à luz as múltiplas figuras cuidadoras que constituíram o universo de parentesco dessas pessoas. Proponho assim uma reflexão sobre as relações entre gênero e parentesco através do modo como essas narrativas apresentam o não reconhecimento de paternidade como uma fuga do pai da responsabilidade, as ambivalências de sentimentos em relação às atitudes das mães e como o parentesco é nelas constituído por meio do cuidado e da afeição. Levanto, por fim, a discussão sobre como as atuais leis e políticas públicas de reconhecimento de filiação podem levar à reafirmação de um modelo normativo de família e reinstituir, em alguma medida, o sofrimento associado à ausência paterna.

Palavras-chave: Família. Reconhecimento de filiação. Cuidado. Parentesco.

\section{Para citar este artigo:}

FINAMORI, Sabrina. Família e cuidado em narrativas de vida marcadas pela ausência paterna. Revista PerCursos. Florianópolis, v. 14, n.27, p. 87 - 115, jul./dez. 2013.

\section{DOI: $10.5965 / 1984724614272013087$}

http: //dx.doi.org/10.5965/1984724614272013087

\footnotetext{
${ }_{1}^{1}$ Parte do conteúdo deste artigo foi adaptada do quinto capítulo de minha tese de doutorado (FINAMORI, 2012), que contou com o financiamento do CNPq e da Fapesp. Uma versão prévia deste texto foi apresentada no Encontro Anual da Anpocs em 2013. Agradeço a Heloisa Pontes que tão atenciosamente orientou a pesquisa original e estimulou a publicação de seus resultados e a Guita Debert pelas sugestões a uma versão prévia deste artigo.
} 


\title{
Family and care in life narratives marked by paternal absence
}

\begin{abstract}
Based on life narratives of children without recognized paternity, the objective of this article is to analyze the care and the reproduction of domestic life through the children's views on the women who were responsible for them during childhood. If, on one hand, these narratives speak of a lack of rights, represented by paternal absence, on the other, they bring out the multiple care givers that make up their family network. Thus, I propose a reflection on the relationship between gender and family ties based on how these narratives present the lack of paternity recognition as the father's escape from responsibility, the ambivalent feeling towards the mothers and how family relationship with them is established through care and affection. Finally, I raise the question of how contemporary laws and public policies on paternity recognition can lead to a reaffirmation of the normative family and reinstate, to some extent, the pain of an absent father.
\end{abstract}

Keywords: Family. Recognized. Care. Kinship. 


\section{Introdução}

Partindo de histórias de vida de filhos sem o reconhecimento legal de paternidade, o objetivo deste artigo é analisar o cuidado e a reprodução da vida doméstica através do ponto de vista desses filhos sobre as mulheres que se responsabilizaram por eles quando crianças. As duas narrativas, que abordo aqui, de Ricardo e Samanta ${ }^{2}$, foram constituídas ao longo de minha pesquisa sobre reconhecimento de filiação baseada nas trajetórias de vida de quatro pessoas adultas em busca do reconhecimento legal de paternidade em correlação ao contexto mais amplo de mudanças nas leis e nas técnicas de investigação dos laços biológicos ao longo do século XX. A partir de narrativas centradas na infância, na ausência do pai, no processo de busca pelo pai, nas relações presentes e nas expectativas futuras tenho analisado como categorias, terminologias e práticas de parentesco, construídas historicamente, acionadas e delineadas cotidianamente nas relações, aparecem nas formas particulares pelas quais a busca pela paternidade pode ser significada.

Ao falarem sobre os sentidos do reconhecimento de paternidade, meus entrevistados encadearam esta questão a outros acontecimentos e personagens relevantes em suas trajetórias de vida, entre os quais mães, avós e tias, que através de práticas de cuidado e educação, se responsabilizaram afetiva e materialmente por eles. Esse artigo se baseia, portanto, nessas histórias, propondo uma reflexão sobre as relações entre gênero e parentesco através do modo como essas narrativas apresentam o não-reconhecimento de paternidade como uma fuga do pai da responsabilidade, as ambivalências de sentimentos dos filhos em relação às atitudes das mães e como o parentesco é nelas constituído por meio de relações de cuidado e de afeição 3 .

\footnotetext{
${ }^{2}$ Os nomes dos meus entrevistados e dos parentes citados por eles foram trocados para preservar a privacidade dessas pessoas. Para os fins do presente artigo, não abordarei as trajetórias dos outros dois entrevistados, que compuseram a pesquisa original.

${ }^{3}$ Embora não caiba aqui uma discussão metodológica mais detalhada, vale apontar que ao abordar as narrativas de vida, meu objetivo foi buscar um aprofundamento qualitativo mais do que uma representatividade quantitativa. Minha análise está baseada, portanto, no discurso narrado, não na observação da ação. Meu fundamento, contudo, na ideia de que a narração é parte da transação social, seguindo a proposta de Barbara Smith (1980) que assinala que essa postura nos encoraja a explorar certos aspectos da narrativa que tendem a ficar obscuros quando o concebemos como texto ou estrutura descontextualizada.
} 
Ainda que essas trajetórias estejam centradas em aspectos íntimos de uma história pessoal de busca pelo reconhecimento paterno, elas estão também encadeadas a um contexto, mais amplo, de leis e políticas públicas, tanto as atuais quanto as que pontuaram o curso de vida de meus entrevistados. Assim, buscarei também trazer à discussão o modo como essas trajetórias se relacionam às mudanças nas perspectivas políticas sobre o cuidado e a responsabilidade sobre os filhos.

Ao longo da maior parte do século $X X$, o reconhecimento da filiação esteve vinculado juridicamente à situação de conjugalidade dos pais. As graduais mudanças nas leis levaram a uma dissociação entre filiação e matrimônio e a uma equiparação de qualificações e direitos entre filhos concebidos em uma união oficialmente reconhecida ou não. A partir de 1977, com a lei do Divórcio (BRASIL, 1977), e, depois, com maior ênfase na Constituição de 1988 e em leis específicas sobre a questão, o reconhecimento legal de paternidade deixa, ao menos em tese, de se vincular à conjugalidade dos pais. Os impactos dessas mudanças foram significativos, especialmente para os filhos nascidos fora de um contexto de conjugalidade entre seus pais, uma vez que até a lei do divórcio de 1977, o reconhecimento, durante o casamento, de um filho tido fora dele estava vetado pelas normas em vigor. Após a Constituição de 1988, além de uma ênfase na não discriminação dos filhos de acordo com a situação de conjugalidade dos pais, a questão que passa a ser importante é também o reconhecimento de paternidade como um direito humano e uma questão de cidadania, postura que é reafirmada pelo Estatuto da Criança e do Adolescente de 1990, que coloca o reconhecimento de paternidade como um direito imprescritível.

Essas alterações legais culminam com a Lei de Paternidade de 1992, que regulamentou, de modo mais amplo, a investigação de paternidade. A partir desta lei, os debates e projetos legislativos apresentados passam a se concentrar na garantia da gratuidade do exame de DNA. (BRASIL, 1992). Visto como uma solução rápida para as disputas jurídicas, o acesso gratuito ao exame para a população sem condições de custeálo passa a ser considerado como uma condição para a cidadania plena. Neste contexto, ainda que essas leis não estejam diretamente ligadas a políticas de combate à pobreza, uma das dimensões que elas destacam é a de que o reconhecimento de paternidade teria 
consequências sociais importantes, na medida em que uma pensão alimentícia poderia ser reivindicada o que garantiria melhores condições materiais para os filhos.

Os filhos que entrevistei, todos nascidos antes da Lei de Paternidade de 1992, apenas reivindicaram o reconhecimento paterno depois de adultos, visando, entre coisas, dar um desfecho para uma trajetória de busca, que, em princípio, era marcada pelo desejo de que o pai voluntariamente os reconhecesse. No caso de Ricardo, que nasceu antes da Lei do Divórcio de 1977, de um relacionamento extramatrimonial, não havia a possibilidade de que o reconhecimento fosse reivindicado durante sua infância, nem se sua mãe assim desejasse, uma vez que homens casados não podiam, até este período, reconhecer, durante um casamento, um filho tido fora dele ${ }^{4}$.

As trajetórias de Ricardo e Samanta, às quais me remeterei nesta ocasião, são de filhos, cuja condição social, durante a infância, se enquadraria no que poderíamos denominar, de modo amplo, como camada popular. Na falta tanto da contribuição financeira paterna quanto de arranjos institucionais que proporcionassem creches para o cuidado dessas crianças, as mulheres que por elas se responsabilizaram recorreram a arranjos domésticos com o objetivo de garantir esse cuidado.

Neste artigo, me concentrarei, portanto, no encadeamento narrativo feito por esses filhos entre a falta de reconhecimento paterno e as práticas de cuidado que lhes foram direcionadas ao longo da vida. Na última parte do texto, recupero as atuais perspectivas legais sobre reconhecimento de paternidade em correlação às trajetórias de vida analisadas.

\footnotetext{
${ }^{4}$ A Lei do Divórcio 1977 introduziu, ainda, mudanças significativas no direito de sucessão. Até aquele momento, "filhos adulterinos", como então eram denominados os filhos provenientes de relações extramatrimoniais, mesmo depois de reconhecidos, tinham direito a apenas metade da herança que coubesse a um "filho legítimo". Na primeira metade do século XX, esse era o ponto nodal da discussão jurídica, pois mesmo os políticos e juristas que eram favoráveis ao reconhecimento de filhos tidos fora do casamento, consideravam que esse reconhecimento não poderia levar ao prejuízo material dos "filhos legítimos". É, então, apenas a partir da lei do divórcio que se iguala o direito ao recebimento de herança "qualquer que seja a natureza da filiação", incluindo-se ainda os filhos adotados. A lei facilitou ainda o reconhecimento dos que já haviam obtido o direito a alimentos. Assim, uma vez dissolvida a "sociedade conjugal" do pai, os filhos que tivessem esse direito estavam dispensados de entrar também com a ação de investigação de paternidade. Para uma discussão mais pormenorizada das mudanças legais, ver o capítulo 2 de minha tese de doutorado (FINAMORI, 2012).
} 


\section{Parentesco e narrativas de vida}

As referências teóricas que norteiam a análise do universo desta pesquisa estão, principalmente, nos campos de estudos de família, parentesco e gênero. Ao abordar as narrativas de vida, me inspiro na proposição de João Pina Cabral e Antonia Pedroso de Lima (2005), segundo a qual, para fins metodológicos, parentesco é "aquilo que o entrevistado achar que é parentesco", de modo que o pesquisador vá se aproximando da ideia que o entrevistado tem de parentesco.

Mobilizo, ainda, o instrumental teórico proposto pelos estudos mais contemporâneos de parentesco, que estimulados pelas críticas de Schneider (1980 [1968] e 1984) e marcados pelo frutífero diálogo com o campo de estudos de gênero, propuseram uma abordagem mais focada nos processos e nos significados do que nos aspectos formais do parentesco. Entre estes, a influente coletânea Cultures of relatedness, organizada por Janet Carsten (2000), que sugere o termo relatedness ao lado ou em substituição ao parentesco. A intenção com o termo é suspender a definição a priori de parentesco para analisar o que é "ser parente" em diferentes contextos, independentemente de laços biológicos. Carsten (2000) assinala que embora o termo relatedness possa estar aberto às mesmas críticas direcionadas ao termo parentesco, o objetivo é colocar entre parênteses um conjunto de suposições para formular as questões de um modo diferente. Essa nova leva de estudos de parentesco nas quais me inspiro está focada em: práticas locais; arranjos domésticos, comportamentos e emoções e nas inter-relações entre gênero e parentesco. Essas análises tendem, ainda, a suspender "biológico" e "social” como termos analíticos ao olhar para cada contexto particular.

Nessa direção, se o exame de DNA tem sido um elemento central, há pelo menos duas décadas, nas narrativas sobre reconhecimento de paternidade, retomando de modo muito acentuado a biologização do parentesco, é preciso estar atento ao fato de que nem todas as narrativas passam exclusivamente por aí. Ao falarem sobre os elementos que fundamentaram o conhecimento deles ou de seus pais sobre o laço de filiação, meus entrevistados evocaram, entre outras coisas: semelhanças físicas, morais, a palavra da mulher ao apontar quem é o pai do seu filho, a relação entre os parceiros. No entanto, o conhecimento sobre o vínculo de filiação não acarreta necessariamente, uma relação que 
meus entrevistados descreveriam como de pai/filho(a). Neste sentido, o sofrimento subjacente a essas narrativas está relacionado ao fato de nem sempre as ações do pai corresponderem ao conteúdo substantivo de como os filhos acham que um pai deveria ser e de como ele deveria agir. Ao mesmo tempo, ainda que essas narrativas sejam marcadas pelo abandono paterno, não significa, de modo algum, que elas não tragam à tona a ação de outros parentes (ou mesmo dos próprios pais) reivindicando a responsabilidade sobre essas pessoas durante a infância. Assim, se o vínculo com o pai é frequentemente conceituado como um laço de sangue, atestado pelo exame de DNA, as narrativas dos filhos mostram que esses sujeitos estão imersos numa rede relacional muito mais ampla, que envolve conexões de muitos tipos, forjadas ou rompidas por meio de práticas de cuidado, lembranças e esquecimentos, sangue, coabitação, comensalidade, responsabilização.

Nessa direção, levo também em conta a perspectiva de Florence Weber (2006) que, ao analisar as atividades de assistência, como o cuidado de idosos e de crianças, considera o parentesco como um conjunto de obrigações morais e legais - "inclusive a obrigação de tomar conta e cuidar" - tanto quanto como um conjunto de direitos econômicos e políticos para a transmissão simbólica e material.

As narrativas de vida foram compostas a partir de entrevistas realizadas entre 2008 e 2011. Quando foram iniciadas, Samanta tinha 27 anos e Ricardo 41. Na época, Samanta estava terminando uma faculdade particular em educação física e trabalhava como funcionária pública; e Ricardo tinha uma formação de nível técnico e atuava como coordenador de programação em uma emissora educativa. Ambos tiveram infâncias entre as camadas populares e apresentaram um processo de ascendência social no curso da vida.

A mãe de Samanta trabalhou como diarista e as suas tias, que foram as pessoas que efetivamente a criaram, eram operárias. A mãe de Ricardo trabalhava como costureira. Ricardo morou na infância numa favela do Rio de Janeiro e Samanta mora até hoje na casa em que nasceu em Sumaré, na região de Campinas. A figura das avós como cuidadoras está também presente nas duas histórias, tanto Samanta quanto Ricardo foram criados pelas avós durante parte da infância. 
Os dois tiveram um nível educacional mais elevado do que suas mães e avós e gozam de uma situação financeira que, atualmente, é melhor do que na infância. Ricardo iniciou um curso universitário, mas não concluiu, tem, contudo, um emprego de nível técnico, estuda francês (já teve a oportunidade de morar um tempo na França vivendo na casa da irmã) e sua filha estuda em escola particular. Samanta estava terminando a faculdade no curso desta pesquisa e dizia que fazer uma pós era seu sonho. Todos eles podem ser considerados atualmente mais como pertencentes às camadas médias do que populares. Samanta vive na mesma casa em que foi criada, mas essa casa passou por melhorias ao longo do tempo. Ricardo saiu da favela há bastante tempo. Todos eles apresentam um processo de autoafirmação, no sentido dado por Duarte e Gomes (2009), isto é, estão entre as camadas menos pauperizadas que tiveram acesso a condições de reprodução que permitiram a ascensão às classes médias. Esse processo de autoafirmação está ligado à classe, idade, desenvolvimento de unidade doméstica, circunstâncias históricas conjunturais (DUARTE e GOMES, 2009). Entre as trajetórias analisadas, a de Ricardo bem exemplifica esse processo. Apesar de ter vivido numa favela e passado por muitas dificuldades financeiras durante a infância, a mãe, que trabalhava como costureira numa pequena fábrica, supriu grande parte das necessidades. Na fala de Ricardo, há muita mágoa em relação ao pai que poderia ter lhe oferecido uma educação melhor, como a que proporcionou às filhas do casamento, contudo, quando sua trajetória é comparada com a de sua família materna, a diferença é significativa. Certa vez, ao contar sobre o preconceito que a mãe havia sofrido da própria família por ter sido mãe solteira, ele falou que, com o tempo, a família teve que se calar, pois apesar de criar o filho sozinha, ela tinha um salário bastante razoável naquele contexto, tendo chegado a ser chefe das costureiras na fábrica onde trabalhava, ao mesmo tempo, as irmãs da mãe, todas casadas na igreja, viam seus casamentos e suas famílias se afundarem em problemas de desemprego, alcoolismo, drogas e, em certa medida, o modo como a mãe e a avó o criaram era visto como algo que deu certo.

Ainda a respeito da questão social, é importante lembrar que, no caso de Ricardo, o pai tinha uma condição financeira muitíssimo superior à da mãe. O pai de Samanta, por sua vez, tinha a mesma situação social que a mãe, os dois viviam no mesmo bairro e 
muitos dos tios paternos e maternos de Samanta, ainda hoje, moram na mesma vizinhança. Embora muitas vezes ela tenha dito que seria bom ter tido a ajuda financeira do pai ao longo da vida, ela reconhece que ele não tem muito a oferecer e chegou a brincar: "Se duvidar, daqui uns anos é ele quem vem me procurar pra pedir ajuda".

As duas trajetórias analisadas são marcadas por narrativas que sublinham o abandono paterno como marco biográfico crucial. Ao narrar o que lhe contaram sobre a gravidez da mãe e seu nascimento, Samanta enfatiza o episódio como uma fuga do pai da responsabilidade. Segundo ela, mesmo sendo solteiro, o pai afirmou ter dúvidas sobre a paternidade e, literalmente, fugiu para não ter que registrá-la. Ricardo, ao contrário, teve, durante a infância, uma convivência com o pai, que o visitava com regularidade. Mais tarde, com o fim do relacionamento entre os parceiros, Ricardo passaria a encontrá-lo no supermercado onde o pai fazia compras. É a partir desse momento que fica patente a diferença no cuidado que o pai dispensava a ele e às filhas. Ricardo conta que o pai enchia o carrinho de supermercado com "queijos, chocolates e danones", sem nada lhe oferecer, produtos que sua mãe nunca podia comprar. A dimensão de classe é, portanto, fundamental para o modo como os filhos narram suas experiências de parentesco e nelas localizam tanto a questão da paternidade quanto os percalços enfrentados por suas figuras cuidadoras ao assumirem a responsabilidade sobre seus cuidados.

\section{Parentesco, práticas de cuidado e responsabilidade}

Minha vó, acho que foi a primeira pessoa no mundo a acreditar em mim de verdade. Acho que nem minha própria mãe acreditou. Ela foi a primeira pessoa no mundo a acreditar no que eu podia fazer como ser humano. (Samanta)

Entre as dimensões supostas em práticas de cuidado, uma delas é a da responsabilidade, que pode se dar através do dispêndio financeiro, do trabalho físico de tomar conta ou mesmo do envolvimento emocional (TRONTO, 1993). Em relações de parentesco, a responsabilização tem também a ver com o estabelecimento da pertença a um determinado grupo e com a possibilidade de algum tipo de influência sobre o futuro da criança. 
Christian Geffray (2000) ao abordar a sociedade macua e concluir que nela não há correspondente exato para o que denominamos como pai ou mãe, traz uma definição interessante de parentesco que poderíamos acrescentar à presente discussão. Segundo ele, se considerarmos o parentesco apenas como uma forma de institucionalização dos fatos biológicos consanguíneos ou dos sentimentos e funções maternas e paternas, então o dispositivo social dos macua, não seria um dispositivo de parentesco. No entanto, Geffray encontra um traço comum entre a sociedade macua e a "nossa" família. Segundo ele, "uma e outra regulamentam uma reivindicação de autoridade sobre a criança". O parentesco poderia, então, ser, neste caso, definido como "o complexo institucional que surge na simbolização do desejo de se apoderar do destino das crianças" (GEFFRAY, 2000, p. 156).

$\mathrm{Na}$ história de Ricardo, embora tenham sido as mulheres que assumiram essa responsabilidade, houve também uma tentativa do pai de tomar o destino da criança para si. Ricardo conta que, depois que nasceu, o pai propôs à mãe que ela the entregasse o bebê. Ele o levaria para casa e diria à esposa que Ricardo havia sido abandonado e que ele desejava adotá-lo. A mãe e a avó de Ricardo se negaram a lhe entregar a criança e a partir daí foram as duas que se responsabilizaram por sua criação.

Se a relação entre os parceiros pode ter um caráter privado, o nascimento de uma criança é sempre um evento público, conforme bem destaca Martine Segalen (2001). Assim, embora tenha havido julgamentos e recriminações pelo fato de a mãe de Ricardo manter um relacionamento com um homem casado, os parentes não fizeram nenhuma intervenção direta na relação amorosa. Mesmo que mal vista, era tratada como algo que dizia respeito a sentimentos e decisões individuais de adultos. Contudo, quando ela engravidou e o filho nasceu, os parentes não se furtaram em intervir na situação. A avó de Ricardo foi enfática em não permitir que o neto fosse levado pelo pai. Sobre as ações da avó, Ricardo conta:

Minha avó ameaçou meu pai. Engraçado que isso foi ele que me contou, ela disse que se soubesse mais uma vez de que algo assim estava planejado iria bater na porta dele para acabar com a história, tornar o fato conhecido para a esposa dele. 
No caso de Samanta, o pai não era casado e os parentes dele não reivindicaram a criança. Ao contrário, ele negou a paternidade e a mãe dele o apoiou. As tias e a avó materna de Samanta assumiram, então, a situação, tendo chegado a ir a uma delegacia na tentativa de resolver o caso. Questionei a Samanta se depois do episódio na delegacia, elas não voltaram a procurá-lo:

Não, acho que se chegou a esse ponto dele falar não quero, não é meu, então, as minhas tias também tinham um certo domínio, assim, sobre... Ele não quer, então tá, bola pra frente, vamos cuidar dessa criança a gente, já que ele não quer. Minha vó e minhas tias que resolveram então.

A gravidez e o nascimento de Samanta já não eram mais assuntos que diziam respeito apenas aos parceiros. Independentemente da vontade do pai ou da mãe, a questão foi assumida pelas tias e pela avó que tomaram as decisões sobre o futuro da criança. A omissão dos parentes paternos é também lembrada por Samanta que considera que se eles tivessem impelido seu pai a reconhecê-la, ele o teria feito.

No âmbito institucional, a responsabilidade sobre uma criança nem sempre é reivindicada, mas atribuída por meio de normas legais e decisões jurídicas. Em cada narrativa particular, no entanto, muito frequentemente são outras pessoas, que não a mãe ou o pai da criança, que tomam para si a responsabilidade e, nessa direção, são as relações de cuidado, afeição e responsabilização que balizam o parentesco.

Michael Lambek (2007) assinala que o cuidado é fundamental nas relações entre memória e parentesco. Lambek nota que a palavra cuidado (care em inglês e suas composições): cuidar de, preocupar-se com, ser cuidadoso, ter cuidados, estar vulnerável, cuidar do que os outros dizem e fazem - mostra, segundo ele, uma dimensão, a um só tempo, semântica, experiencial e prática na qual parentesco e memória estão mutuamente implicados. Cuidar, para Lambek, é uma forma de lembrar característica dos ethos e das práticas de parentesco, que inclui os ascendentes e mesmo os mortos.

A relação entre Samanta e a mãe é profundamente marcada pelo fato de Marta ter deixado a filha para que ela fosse criada pela avó e pelas tias. Ao longo da vida, os papéis por ela esperados, de mãe e filha, muitas vezes, se inverteram e Samanta teve (e ainda tem) que cuidar da própria mãe. Quando Samanta tinha cerca de quatro anos, Marta foi morar com um parceiro e não levou a filha consigo. Depois disso, elas nunca mais 
voltaram a morar juntas. A relação de Marta com o parceiro não se prolongou e, depois da separação, Marta ficou sem ter onde morar, vivendo, segundo Samanta, como uma nômade, mas, ainda assim, não retornou à casa da família. Mais tarde, quando Samanta tinha doze anos, a mãe foi morar com outro parceiro com o qual teve mais dois filhos, um menino e uma menina, que, no momento das entrevistas, tinham, respectivamente, quatorze e oito anos. Marta e o companheiro tiveram uma relação duradoura e ele veio a falecer quando ela estava grávida da segunda filha. Samanta conta que a morte do parceiro desestruturou, mais uma vez, a vida da mãe e foi um momento marcado por muito sofrimento. Nessa época, Samanta tinha dezenove anos e já havia começado a trabalhar e, a partir daí, passou a oferecer à mãe também um suporte financeiro.

Antes da decisão de entrar com o processo de investigação de paternidade, eu havia lhe questionado sobre a possibilidade de uma ação judicial e, naquele momento, Samanta falou da humilhação que significaria, não só para ela própria, mas também para sua mãe, ter de provar a paternidade, uma vez que ela considerava que o processo retomaria tudo que a mãe passara no período da gravidez. Quando ela efetivamente entrou com o processo, a mãe, contudo, apoiou sua decisão e a ajudou a procurar uma advogada.

As ações da mãe nem sempre corresponderam, no entanto, ao conteúdo substantivo do que Samanta considera como uma mãe. Não é raro, desse modo, que ela afirme que as tias foram efetivamente suas figuras maternas, seja pela resolução de questões práticas, pela orientação que Ihe deram na vida, pelo afeto, enfim, pelo cuidado. Relacionamentos similares, contudo, nem sempre envolvem a exata substituição de termos. Assim, embora tenha sido criada pelas duas tias e as considere como mães, ela se remete a cada uma delas pelo termo tia e a palavra mãe é reservada à mãe biológica. Ao mesmo tempo, ela é enfática sobre o afeto e a consideração que tem pelas tias e deixa claro que se sente obrigada a elas, no sentido de lhes endereçar cuidados na velhice, por exemplo.

As trajetórias de meus entrevistados estão também próximas daquilo que Claudia Fonseca (1995) descreve como “circulação de crianças”. Meus próprios entrevistados embora não tenham circulado entre diferentes casas, tiveram múltiplas figuras 
cuidadoras, além da própria mãe, e viveram em contextos em que essa não era uma realidade incomum. Fonseca (1995) destaca que a "circulação de crianças" não necessariamente significa o abandono ou que a mãe não participe da vida dos filhos. Em muitas circunstâncias deixar um filho na casa de um parente pode ter a ver com a falta de condições materiais da mãe para cuidar da criança, de modo que a responsabilidade é dividida com outros membros da parentela ou mesmo com não parentes. No caso de Samanta, quem circulou não foi ela, mas a mãe, que se mudou da casa onde viviam e a deixou para ser criada pela avó e pelas tias. A avó de Ricardo receberia outra neta, Priscila, em sua casa quando a mãe não teve condições de criá-la e Ricardo se refere a ela como uma "irmã de criação". Mais tarde, Priscila teve também uma neta sem reconhecimento de paternidade, que circulou entre diferentes casas, tendo vivido, por um período, com a mãe de Ricardo. Durante a infância, Ricardo teria, ainda, como figura cuidadora Carina, uma prima, sete anos mais velha. Os dois se tornaram, segundo ele, amigos inseparáveis até sua morte trágica por atropelamento.

Como bem observa Claudia Fonseca (2006), adquirir novos pais e irmãos não acarreta necessariamente a ruptura de relações anteriores, ao contrário "os arranjos de criação servem para aumentar o círculo de pessoas significativas no universo social de um indivíduo" (FONSECA, 2006, p. 24). Neste sentido, o parentesco é expresso pelos filhos em suas muitas dimensões: tanto por meio do desejado reconhecimento do vínculo biológico com o pai como também (e ao mesmo tempo) por essas múltiplas relações que envolvem afeição, responsabilização e cuidados mútuos.

Embora Ricardo tenha narrado com eloquência e profundidade sobre sua rede de parentesco, havia certo comedimento ao falar da relação com a mãe. Numa de nossas primeiras conversas, ele ressaltou que a mãe "nunca pleiteou nada na justiça". Ao longo da pesquisa, tornou-se claro que este era o ponto nodal da relação. Embora existissem outros problemas, a questão da paternidade era central na expressão de seus sentimentos ambivalentes pela mãe. Para Ricardo, ela deveria ter sido mais incisiva com o parceiro no passado:

[Minha mãe] devia ter procurado de maneira mais obstinada o meu pai... ela deixou correr frouxo, depois que me tornei adolescente disse que se eu quisesse procurar ver o meu pai só dependeria de mim, mas as coisas não eram exatamente assim, não podia simplesmente bater na porta do 
meu pai, coisa que eu acho que ela deveria ter feito, aparecer comigo lá na porta dele.

Durante os anos em que tivemos um contato regular, Ricardo passou por fortes abalos na relação com o pai e as irmãs, com as quais mantinha até então uma relação próxima. Pouco antes do início da pesquisa, numa briga entre mãe e filha, a irmã de Ricardo havia revelado que Rogério, que frequentara a casa por cerca de vinte anos como amigo da família, era, na verdade, Ricardo, fruto de uma relação extraconjungal do pai. Depois da revelação desse segredo, Ricardo passou a insistir que o pai, enfim, formalizasse o reconhecimento de paternidade, o que não ocorreu. Diante da crise familiar que se instalou, não só a relação de Ricardo com o pai foi abalada, mas também com as irmãs. Em determinado período da pesquisa, essa questão foi recorrentemente tematizada por ele, e nesta época, questionei se ele havia compartilhado com a mãe as angústias e dores daquele momento:

Não contei.... na verdade converso pouco com ela sobre isso, tenho minhas restrições por conta de culpá-la por estar acontecendo isso, acho que ela tinha que ter feito isso no passado, é um sentimento que tento afastar, mas não consigo, ela sempre fala: "coloca logo na justiça, tá esperando o quê? que ele morra?” mas eu não falo nada.

Quando ele decidiu buscar judicialmente o reconhecimento de paternidade perguntei se ele considerava que, em alguma medida, o processo poderia ter um efeito na relação entre ele e a mãe. Ricardo afirmou categoricamente que não. Do seu ponto de vista, a relação com a mãe, há muito tempo, se desvinculara da questão da paternidade. Na sinopse que escreveu para a advogada montar o processo, entretanto, ele detalhou o período temporal do relacionamento entre a mãe e o pai justamente como uma forma de defesa da honra de sua mãe:

eu fiz questão de citar esse tempo por conta da minha mãe... meu pai andou dizendo para as minhas tias e para a esposa dele que tudo não passou de uma noite apenas.... Isso manchava a minha mãe e então coloquei isso para defendê-la.

Nesse momento, Ricardo discorreu sobre suas dificuldades em discutir com a mãe sobre o passado e admitiu que a culpava pelo fato de ela não ter exigido que o pai o 
reconhecesse quando ele ainda era criança. Destacou, no entanto, que o relacionamento com a mãe estava muito melhor do que há alguns anos atrás. Ainda assim, arrematou dizendo que só Freud poderia resolver seus problemas com ela:

É uma relação em que eu me avalio o tempo todo, eu fico me posicionando quanto a esta relação, tento ser mais carinhoso, procuro entender... quero sempre melhorar... porque no fundo eu me cobro quanto aos sentimentos que tenho dela, vem aquela frase na cabeça: "só se colhe o que se planta". Aí eu procuro mudar e focar no fato que ela só tem a mim, que realmente eu devo muito a ela e tento melhorar a relação.

Na medida em que minha análise é baseada em narrativas de vida, não parece demais assinalar que também as memórias do passado podem ser, muitas vezes, afetadas por categorias presentes. Ian Hacking (1999) oferece, nessa direção, alguns insights interessantes para pensar a questão a partir das ideias de Nelson Goodman. Hacking (1999) assinala que entendemos muito bem quando novas categorias oferecem novos modos de ação e novas escolhas, mas, em geral, consideramos o passado como algo fixo. Contudo, ele assinala:

Se novas categorias são selecionadas, então o passado pode ocorrer num novo mundo. Os eventos de uma vida podem agora ser vistos como eventos de um novo tipo, um tipo que não podia ser conceituado quando o evento foi experienciado ou $\mathrm{o}$ ato performatizado. O que nós experienciamos é relembrado de um modo novo e pensado em termos que não poderiam ter sido pensados naquela época. As experiências não são apenas redescritas; mas re-experienciadas (HACKING, 1999, p. 130, tradução minha) $)^{5}$

Mesmo sabendo das dificuldades que teria havido para que, em sua infância, entre as décadas de 1960 e 1970, a mãe entrasse com um processo legal de reconhecimento de paternidade contra um homem casado, Ricardo, por diversas vezes, relembrou e reexperienciou o passado com algumas noções presentes sobre o reconhecimento de paternidade como direito humano e como questão de cidadania. Num misto de mágoas

\footnotetext{
${ }^{5}$ No original em inglês: "If new kinds are selected, then the past can occur in a new world. Events in a life can now be seen as events of a new kind, a kind that may not have been conceptualized when the event was experienced or the act performed. What we experienced becomes recollected anew, and thought in terms that could not have been thought at the time. Experiences are not only redescribed; they are refelt". (HACKING, 1999, p. 130).
} 
guardadas em relação à mãe e na ideia de que seus direitos nunca foram respeitados, ele, por diversas vezes, deu a entender que sua trajetória poderia ter outros contornos se a mãe tivesse insistido em fazer com que o pai assumisse a paternidade quando ele ainda era criança.

\section{Corporalidades e parentesco}

Se a conexão entre pessoas é geralmente pensada como algo que repousa fora dos corpos, através de todo tipo de comunicação ou formas de associação, o parentesco é, segundo Strathern (2005), o lugar onde os ocidentais pensam sobre as conexões entre os próprios corpos. Assim, se os ocidentais usam o corpo para pensar sobre a unicidade do indivíduo, eles o usam também para falar do modo como as pessoas se conectam umas às outras, não através do que elas compartilham em geral (humanidade), mas do que é transmitido em particular. A partir daí é possível também traçar conexões específicas entre pessoas marcadas por diferentes graus de proximidade relacional.

Baseada no estudo de Daniel Miller (1997) sobre as mães britânicas de classe média, Strathern (2005) destaca a dimensão da corporalidade num sentido que não se restringe ao que pensamos como biologia. Ao contrário, Strathern assinala que essas mulheres compartilham duas vezes os corpos com seus filhos: o corpo biológico, genético e o corpo como sinal da devoção ou da negligência delas pelos filhos. 0 conhecimento que elas têm sobre o mundo pode, assim, ser usado para moldar os corpos das crianças: o que se come, que tipo de exercício se faz, o amor que se dá e os resultados que isso terá na corporalidade. Na situação apontada por Strathern, a ênfase está na responsabilidade colocada sobre as mães em virtude do conhecimento delas sobre os efeitos que as substâncias, brinquedos ou comportamentos teriam sobre as crianças, de modo que o conhecimento que elas possuem impõe uma obrigação de agir. O sucesso da mãe é, por assim dizer, medido pelo sucesso do filho. Desse ponto de vista, as pessoas agiriam sobre as outras do mesmo modo que agem sobre o mundo.

As situações que trato aqui estão muito distantes do contexto específico da classe média britânica ao qual Strathern se refere. A questão que importa reter, a partir de 
Strathern (2005), para a presente análise é que as figuras cuidadoras que Samanta e Ricardo tiveram ao longo da vida agiram sobre eles com base no conhecimento que tinham sobre o mundo, vislumbrando, aparentemente, os efeitos de suas ações no futuro dessas pessoas. Em muitas ocasiões, esses filhos consideraram que os investimentos feitos sobre eles por suas figuras cuidadoras eram superiores aos recebidos por seus amigos e parentes, que viviam em contextos similares. As mulheres que cuidaram de meus entrevistados recorreram às mais diversas estratégias, tais como: oferecer uma educação rigorosa, impedir o trabalho infantil, restringir a circulação em certos horários e locais da vizinhança, cortar um bife para a marmita ou deixar um copo de leite. Em cada caso particular, essas ações visavam proteger a criança, que estava sob seus cuidados, de um ambiente que poderia ser considerado perigoso e proporcionar, ao mesmo tempo, condições para que tivesse um bom nível educacional, não engravidasse na adolescência ou se casasse com uma pessoa violenta, não se tornasse traficante ou desempregado. $O$ orgulho dessas mulheres pelo sucesso de suas ações aparece também nas narrativas dos filhos. No caso de Ricardo, cheguei a questionar se o orgulho da mãe não estaria associado às comparações feitas no passado entre ela e as irmãs que se casaram formalmente, e ele considerou que, de fato, ela deve ter ficado satisfeita por poder mostrar aos parentes o sucesso do filho que seria, porque não, seu próprio sucesso.

Na narrativa de Ricardo, a questão da corporalidade está presente de modo mais acentuado nas ações da mãe, que, durante a infância, era muito rígida e batia nele com frequência. A justificativa que a mãe usava para a sua rigidez era o fato de viverem num ambiente "repleto de marginais" e "não haver um homem na casa para imprimir respeito".

Um duplo objetivo era explicitado pela mãe de Ricardo ao recorrer à violência física - de um lado livrá-lo do destino dos parentes: “álcool, drogas, desemprego" e, de outro, impedir que Ricardo fosse canhoto como o pai:

Minha mãe reclamava muito da minha caligrafia, mas culpa dela mesma, quando eu nasci era canhoto assim como meu pai, acho que te contei o episódio em que ele jogou o chaveiro e eu engatinhando peguei com a mão esquerda, pois bem, daí por diante minha mãe começou a bater na minha mão esquerda para tirar e me obrigou a usar a direita. Ela me deu um caderno de caligrafia para melhorar. Numa das páginas o exercício era a escrita do nome, você escrevia várias vezes e foi aí que comecei a 
escrever o nome usando o sobrenome dele, mas depois eu retirava as folhas. Pra ela não ver? Sim, pra ela não ver. Ela me tirou a esquerda por conta do meu pai. Aquilo era um gostinho para ele que ela não queria oferecer.

Essa intervenção corporal tem aspectos muito interessantes em termos de gênero e de parentesco. O episódio ao qual Ricardo se remete na fala acima se iniciou com uma dúvida de paternidade sugerida ao pai por um admirador da mãe que desejava assumir a criança que ele sabia ser do outro. Quando relatou o episódio, Ricardo assinalou que o pai jogou o chaveiro e ele engatinhando pegou com a mão esquerda, tendo sido justamente o fato de o bebê ser canhoto que fundamentou a certeza do pai sobre o vínculo, já que todos os homens da família seriam canhotos. A ação da mãe visava, então, não apenas torná-lo menos parecido com o pai, mas, ao que parece, tinha uma intenção ainda mais profunda - suprimir uma característica física que marcaria, de algum modo, a masculinidade naquele grupo de parentesco e, mais que isso, apagar essa característica do único filho homem que o parceiro teria. Como disse Ricardo, "era um gostinho para ele que ela não queria oferecer”.

Ricardo passou a escrever com a mão direita, mas ressalta que as semelhanças físicas com o pai e outros parentes não foram apagadas. Em diversas ocasiões, ele destacou o quanto era fisicamente parecido com o pai e com os outros homens da família. Também relatou a cumplicidade masculina que havia entre os irmãos do pai, “irmãos homens", ele sublinhou, que foram os primeiros a saber de sua existência, o que era justificável, na medida em que "para ele [o pai], era normal ter filhos fora do casamento". A cumplicidade masculina envolvia ainda presentear o filho com revistas Penthouse, que meu entrevistado descreveria como "revistas de mulheres nuas". Quando Ihe perguntei sobre a participação do pai em sua educação ele a apresentou do seguinte modo:

praticamente... ele nunca me orientou.. deu informação... ele falava das coisas dele... ou então acabava falando sobre as revistas... melhor sobre - conteúdo, acho que rolava uma preocupação quanto à minha sexualidade motivada pelo fato de eu ser criado somente com mulheres. 
Embora tenha afirmado o quanto gostava das "revistas de mulheres nuas" com as quais o pai lhe presenteava, em outras ocasiões, ele se afastou, em sua narrativa, do modelo de masculinidade que o pai havia lhe apresentado. Certa vez, ao contar sobre seu incômodo diante de um comentário do pai que disse que ele era "carinhoso demais" com a filha e que isso não era normal, Ricardo analisou:

Me chocou! A frustração dele [do pai] era que ele provavelmente nunca foi capaz de ser tão carinhoso com as filhas da maneira que sou com a minha, só conseguiu dar carinho em troca de sexo e acaba achando que todo homem é assim.

Em outra ocasião, Ricardo afirmaria, categoricamente, que sempre quis ser pai para agir diferentemente de seu próprio pai. Em sua narrativa, a experiência como pai o levou a desconstruir o sentido até então atribuído à paternidade e lhe permitiu repensar as ações do pai. Conforme assinala Joan Scott (1991), a experiência pode tanto confirmar o que já se sabe (nós vemos o que aprendemos a ver) como também contrariar o que tomamos como garantido (quando diferentes significados estão em conflito, reajustamos nossa visão para ver o conflito e resolvê-lo). Scott (1991, p. 779) assinala que os sujeitos "são constituídos através da experiência"; e a experiência é um evento linguístico, que embora não ocorra fora dos significados estabelecidos também não está confinada a uma ordem fixa de significados. Na narrativa de Ricardo não apenas o conceito que ele tinha sobre a paternidade esbarrava nas ações do pai, que não correspondiam ao esperado, mas, mais que isso, quando ele próprio experiência a paternidade, o conceito é confrontado por sua experiência corpórea de "sentir o filho", se perceber como o "gestor inicial daquela vida" e questionar, como ele fez certa vez, "por que ele não me viu assim?".

Em relação à mãe, embora Ricardo tenha expressado ressentimentos relacionados aos episódios de violência física e à própria história de paternidade, ele reconhece que ela Ihe deu todo provimento financeiro que foi possível, ao contrário do pai que, apesar da condição financeira muitíssimo superior, quase nada lhe ofereceu. Ricardo avalia que o sucesso de sua trajetória está relacionado ao fato de sua mãe ter lhe impedido de trabalhar cedo permitindo assim que ele tivesse mais anos de educação. Na visão da mãe, contudo, a educação rígida e as pancadas foram a causa de uma trajetória mais bem 
sucedida do que a dos sobrinhos, tendo livrado o filho de um futuro de marginalidade, ligado ao crime ou aos vícios. Esse sucesso estaria, agora, patente para toda a família, uma vez que o filho saiu do ambiente onde foi criado, tem um nível educacional mais elevado e uma renda melhor do que a de qualquer outro parente.

Ricardo e Samanta foram criados por um determinado período pelas avós e os investimentos que essas avós fizeram sobre os netos foram, muitas vezes, vistos dentro do próprio grupo de parentesco como superiores aos que eram feitos sobre outras crianças daquela mesma rede, provocando comparações e ciúmes.

No caso de Ricardo, a relação entre ele e a avó provocava reações mais acaloradas das tias que criticavam não só os cuidados excessivos da avó com o neto, mas também o modo como a mãe de Ricardo estava criando o filho:

sempre ficou explícita a "preferência" da minha vó por este neto, logo o neto bastardo, lógico, deu ciumeira, lembro de minhas tias dizendo que eu seria um "inútil", que minha mãe estaria ferrada comigo se fosse depender de mim para trabalhar ou ser alguém na vida. Minha mãe não deixava eu trabalhar cedo, coisa comum naquele ambiente de pobreza, elas estavam forçando a barra para que eu trabalhasse logo, que senão eu seria um vagabundo, coisas assim que eu ouvia.

Na narrativa de Samanta, as intrigas se concentrariam na relação com seu tio Francisco e os filhos dele. A casa onde Samanta morava foi construída num lote comprado pelas tias em parceria com Francisco. Ele construiria sua casa na metade do terreno e as tias de Samanta na outra, onde ficaria morando também a avó. Uma das filhas de Francisco, Eduarda, um ano mais nova que Samanta, era também cuidada pela avó enquanto seus pais trabalhavam e os cuidados que a avó dispensava a cada neta fomentavam comentários:

Acho que esse ciúme, as intrigas, o que deu o que falar foi em relação a isso talvez, da minha vó dar mais atenção a mim que tava ali junto com ela do que aos filhos dele, que tinham quase a mesma idade que eu, mas não moravam junto com ela, moravam próximo, mas não junto, acho que isso aí causava um certo desconforto, ter certas regalias com minha avó que os outros primos não tinham.

Eu acho que eles cobravam um pouco minha avó esse cuidado, então, assim, minha avó fazia tudo por mim, tudo, tudo mesmo, me dava de tudo que ela podia, que estava ao alcance dela, então, eu acho que isso gerava um pouco de conflito, por que pra mim e não pra outra, mas a 
outra tinha o pai e a mãe junto e eu naquela situação. Então, eu soube que isso aconteceu, que teve esse tipo de comentário e cobrança.

Samanta enfatizou que, durante a infância, o sentimento de desigualdade em relação aos que tinham um pai reconhecido pesava muito mais dentro do próprio grupo de parentesco do que nas relações de amizade ou de vizinhança. Nesse sentido, a relação entre Samanta e a prima foi também marcada pela questão da paternidade. Assim, se as ações da avó em relação a uma das netas provocavam reações enciumadas na outra, na relação entre as duas, Samanta afirma que ela própria sentia inveja ou ciúme pelo fato de Eduarda ter um pai e que também a prima acionava a paternidade como um bem simbólico que, naquela relação, apenas ela possuía:

Eu acho que eu sentia uma ponta de ciúme, não sei se é inveja, da minha prima Eduarda, a gente tinha mais ou menos a mesma idade, então, algumas coisas ela tinha e eu não tinha. "Ah, o meu pai", tipo, enchia a boca pra falar. Isso me incomodava um pouco, eu ficava um pouco chateada. Parece que enchia a boca, "porque meu pai me deu", não sei se era pra provocar, porque tem criança, por mais boa que é, tem um lado que quer provocar, cutucar a outra, a gente era muito amiga, mas sempre tinha aquele lado meio da rivalidade, mesma idade e tinha as coisas com a minha avó, depois minhas tias, que me davam. Então, tinha um pouco de ciúmes por parte dela. Tinha uma coisa de mostrar que ela tinha uma coisa que eu não tinha, que eu nunca ia poder ter. Então, ela fazia questão de falar: "ah, o meu pai".

Ainda na infância de Samanta, contudo, a avó faleceu num acidente de carro, no qual estavam outros parentes, inclusive Lúcia, uma das tias que criaram Samanta. Eles voltavam de uma viagem a Minas onde haviam ido passar as festas de fim de ano. A avó não morreu na hora, ficou consciente por algum tempo e Lúcia, que a acompanhou na ambulância, conta que a última coisa que ela disse foi um pedido para que ela cuidasse de Samanta. A tia conta que as palavras da avó foram:

“- cuida da Samanta porque a mãe dela não vai cuidar, ou não vai cuidar dela direito".

Foi a última coisa que ela falou na vida, enquanto tava viva, aí fechou o olho e acabou, foi a última coisa que ela pediu, pra minha tia cuidar de mim. 
Quando a avó morreu, Samanta havia acabado de completar sete anos e, até então, morava com a avó e as duas tias. Depois do falecimento, Helena, uma das tias, pediu para que a mãe de Samanta voltasse para casa para cuidar da criança; e ela se negou. A morte da avó coincidiu com o início das aulas e Samanta relata que um dos grandes problemas foram os arranjos práticos em relação aos seus cuidados. As duas tias trabalhavam numa indústria metalúrgica e saíam de casa para o trabalho antes de o sol nascer:

a perda dela [da avó] fez falta no sentido não sei se físico, do cuidado, de ter alguém que cuidasse de mim, o sofrimento, sofrimento mesmo, eu acho que eu não tive, não sei se porque minhas tias me acolheram de uma maneira satisfatória, eu não consegui assimilar essa questão da perda da minha avó, eu acho que não sofri por isso. O mais foi mesmo a questão de com quem eu ia ficar, quem ia me levar.

Foi um período muito complicado, eu lembro que eu saía da escola e tinha uma creche ao lado da escola, então eu ia pra escola de manhã, com minhas primas, com amigos, ia todo mundo. Aí eu saía da escola e ia pra creche. Ficava o dia todo, fazia minhas refeições. Minhas tias chegavam em casa, eu tinha almoçado na creche. Isso foi até uns 8 , o começo dos 9 anos. Aí a creche ia mudar não ia aceitar mais, ia ser só educação infantil, tinha idade certa pra ficar lá e eu não podia mais ficar. Aí comecei a ficar em casa de vizinho, uma prima cuidava de mim, era uma coisa muito complicada. E eu acho que fui subnutrida antes dos 9 anos, eu pesava 25, 27 quilos, porque eu não tinha lugar certo pra ficar direito, foi muito complicada a perda da minha vó... No dia que minha tia falou: "Samanta, você não quer ficar em casa sozinha? você sozinha, pra não ficar de casa em casa?" Teve um dia que elas chegaram... elas trabalhavam na mesma empresa, e eu tava sentada na calçada na rua em frente à minha casa. A vizinha tinha que sair, resolver uns problemas e disse: "elas [as tias] já tão chegando, fica aí na rua". Trancou o portão e eu fiquei sentada na porta. Minhas tias chegaram e eu tava sentada lá. Elas não aceitaram aquilo, aí eu comecei a ficar sozinha em casa com 9 pra 10 anos. Eu tinha muito medo. Elas saíam muito cedo de casa e tava ainda escuro. Ficava do lado de fora da casa, achava que ali não ia ver nada que me assustasse.

As tias não se casaram nem tiveram filhos. Quando perguntei sobre o assunto, Samanta respondeu: "eu sou a filha delas". As tias parecem ter funções bem demarcadas na vida de Samanta. Helena cuida das coisas práticas e foi legalmente tutora de Samanta para poder colocá-la como dependente em seu convênio médico. Quando Samanta está deprimida por causa do pai, ela tenta falar com algum parente para que ele entre em contato. Antes de Samanta decidir entrar com a ação na justiça, Helena dizia que se o pai 
aparecesse novamente, ela o colocaria contra a parede para que ele fizesse o reconhecimento legal, uma vez que Samanta não tinha coragem de pedir e o pai nunca se manifestou a respeito. Samanta pontua que a relação com Helena é também mais conflitante, ela é controladora e faz muitas cobranças. Ao mesmo tempo, Samanta diz que ela e a tia são muito parecidas: "A gente gosta de conversar sobre as mesmas coisas, gostamos de assistir futebol juntas". Samanta considera que Helena tem uma personalidade próxima da sua e pelo fato de as duas serem muito "estouradas acaba, saindo faísca".

Lúcia é a figura calma, serena, segundo Samanta, o lado sentimental. Quando ela está triste por causa do pai, enquanto Helena tenta tomar providências práticas para resolver, Lúcia oferece o ombro para ela chorar. Samanta acha que o pedido da avó para que Lúcia cuidasse dela ficou muito marcado e enumera os cuidados que ela tem:

ela faz coisas assim... coisas simples, quando eu trabalhava lá no outro emprego, que eu não almoçava em casa, trabalhava o dia todo e aí ela fazia minha marmita, ela mandava minha carne picada pra eu não ter trabalho, pra não perder tempo cortando a carne, que na marmita ela sabe que não dá pra fazer isso, então, ela mandava o bife picado, todos esses cuidados. Eu chego em casa, meu copo de leite tá pronto, quem faz é ela, deixa pronto, que é só eu chegar e tomar.

O ápice do orgulho das tias pela educação que lhe proporcionaram foi sua formatura:

A Helena.... assim... é como a Lucia, mas ela sempre pensa mais na questão do futuro, de ter uma vida melhor, de se dar bem. Então, ela sempre me aconselhou muito, por esse lado. Então, pra ela, minha formatura foi um auge de felicidade, pra vida das duas, pra ela também. Sabe, anel de formatura, vai lá, parcelou para o resto da vida pra me dar um anel de formatura, eu falava: "nossa, gente, não tem necessidade de fazer isso", mas ela fez questão de fazer isso, então, pra ela, é um orgulho muito grande, eu ser experiente, eu vencer, eu ter minhas conquistas, é o lado da razão mesmo, a Helena é muito razão mesmo na minha vida.

Mais de uma vez, Samanta teceu reflexões sobre os efeitos que os cuidados dispensados pelas tias tiveram em sua trajetória em comparação às de suas amigas:

eu acho que minha educação... não tive tanta liberdade quanto minhas amigas tiveram, por exemplo. Mas acho que no fundo foi até bom pra mim, que minhas amigas tiveram tanta liberdade que hoje não têm a 
liberdade que eu tenho, né. Minhas amigas que iam pra pracinha, uma, hoje tem dois filhos, já apanhou do marido, ele entrou na casa e tacou fogo nas coisas, o cara era um drogado, eu não sei se ela chegou a se envolver com isso, mas ela conviveu com uma pessoa drogada. A gente era de um círculo de quatro garotas, aí cada uma tomou um rumo diferente e eu achava que eu era muito presa, elas tavam indo curtir e eu não, minhas tias não deixavam porque era perigoso

Os múltiplos cuidados objetivavam não apenas dar-lhe autonomia através da educação e profissionalização, mas convergiram numa apreensão extremada com o tipo de parceria amorosa que Samanta teria no futuro e, principalmente, em tomar todas as precauções para que a história da mãe não se repetisse na da filha:

com namorado sempre teve aquele cuidado, aquele medo, aquele receio, das coisas darem errado, então, estavam sempre orientando, "olha, se for fazer isso, tem que ser assim, toma cuidado, não confia demais nas pessoas, você pode quebrar a cara", sabe, sempre esses conselhos assim, acho que pra não me ver sofrer... cuidados que qualquer pai ou mãe tem.

\section{Das histórias de vida às atuais políticas públicas: questões e problemas}

“Talvez eu poderia ser um pouco melhor do que eu sou hoje, se eu tivesse tido uma vida normal, com pai, mãe, gato, papagaio, talvez não”. (Samanta)

Em publicação recente sobre o tema, Marshall Sahlins (2012) se opõe à definição do parentesco como natureza, propondo, ao invés disso, o termo "mutuality of being" para enfatizar que o parentesco se refere a pessoas que são intrínsecas, imprescindíveis à existência uma da outra. Nas narrativas que analisei meus entrevistados destacaram, com muita frequência, as dimensões do parentesco que extrapolam o sentido que nominaríamos como biológico, natural ou genético, definindo essas relações muito mais por práticas de cuidado, de educação e de afeto, vistas como promotoras de um efeito duradouro no futuro das pessoas e de uma conexão profunda entre meus entrevistados e aqueles que se responsabilizaram por eles.

Nessa direção, uma questão inesperada durante a pesquisa foi que a despeito dessas narrativas falarem sobre uma diversidade de experiências de parentesco, 
marcadas por relações de cuidado, afeto e responsabilização, elas também se remetiam a uma ideia de "família normal”. Ora evocada ao contarem episódios de discriminação que eles ou suas mães sofreram, ora ao refletirem sobre a própria experiência familiar. Dentro da noção sobre o que seria uma família adequada à norma apareceram, entre outros elementos: o fato de pai e mãe serem casados ou viverem juntos, ter um pai reconhecido ou, ainda fazer parte de um grupo que se reconheça mutuamente como uma família. Tais elementos podiam ser citados juntos ou separadamente; no caso de Samanta, por exemplo, ela faz parte de um grupo que se reconhece mutuamente como uma família (ela e as duas tias), embora a vida dela não se enquadre no que ela denomina como uma "vida normal”, que consistiria em morar "com pai, mãe, gato e papagaio".

Desse modo, ainda que meus entrevistados tenham discorrido longamente sobre uma diversidade de relações de parentesco, suas narrativas estão também permeadas por um modelo normativo de família, que supõe a existência de um pai reconhecido. Nessa direção, vale lembrar que o reconhecimento de filiação esteve pautado, ao longo do século XX, pela relação entre conjugalidade e filiação. Se no âmbito legal, gradualmente se dá uma desvinculação entre os termos, na prática essa dissociação é ainda incompleta. $\mathrm{Na}$ experiência dos filhos que entrevistei nos últimos anos esses elementos permanecem entrelaçados. Ao narrarem suas histórias, os contextos em que o reconhecimento de paternidade é visto como um privilégio social e simbólico, remontam, em geral, ao fato de pai e mãe não serem casados entre si, à desigualdade social em relação aos eventuais irmãos - filhos do pai com a esposa com quem é legalmente casado - e às comparações feitas dentro do grupo familiar entre diferentes modelos de filiação. Não foi incomum que a busca pelo reconhecimento de paternidade fosse narrada como uma forma de reparar, em alguma medida, o sofrimento decorrente das discriminações sociais, sofridas no passado, em virtude da ausência paterna. Ao falar sobre suas motivações para entrar com o processo Samanta explicou:

Eu fiquei todo este tempo esperando que ele [o pai] me procurasse pra isso, aí meio que bateu uma raiva. Pensei assim, se fiquei quieta... e ele não se manifestou... vou correr atrás, quero ser reconhecida assim como os filhos dele são. Tava me sentindo pra baixo... mal comigo mesma, aquela coisa de identidade, sentimento envolvido, aí, resolvi agir assim, pois sei que ele nunca virá atrás de mim pra isso. 
Para esses filhos, o processo judicial é também visto como uma forma possível de agência à qual tiveram acesso apenas depois de adultos e que pode ser empreendida independentemente da vontade do pai ou da mãe. Em muitas circunstâncias, a busca pelo reconhecimento legal da paternidade é considerada ainda como uma tentativa em dar uma segunda chance para o que o pai aja de modo distinto do que teria feito no passado. Nesta direção, o sentido atribuído ao reconhecimento de paternidade é fortemente influenciado pelo contexto jurídico-legal e pelo peso socialmente atribuído ao exame de DNA. Mais do que confirmar uma informação ou proporcionar o reconhecimento legal de uma paternidade, um resultado positivo de um teste de paternidade pronunciado por um juiz é visto como algo que aquilata diferentemente a decisão do pai em assumir ou não a função paterna. Isto é, embora continue sendo uma decisão do pai aceitar ou não o relacionamento com o filho, essa decisão estará marcada pelo aceite ou rejeição de alguém, biológica e legalmente, identificado como filho.

As atuais leis e políticas públicas têm instituído, com efeito, uma importante possibilidade de agência para as mulheres e para os filhos adultos, não só pelas consequências materiais decorrentes do reconhecimento, mas também, no caso dos filhos, por promover um desfecho, ainda que jurídico, para uma história pessoal que muitos deles consideravam mal resolvida. Essas mesmas leis e políticas têm, contudo, reforçado a ideia de que ter um pai reconhecido é um componente central para ter uma “trajetória mais saudável”, para ser um “cidadão completo” e, portanto, para estar dentro da norma. Tal discurso tem sido atualizado nas narrativas dos filhos, nas quais o desejo de ter um pai reconhecido, remete-se, com frequência, a um desejo por se enquadrar num ideal normativo de família. Sem negar os componentes individuais e psíquicos inscritos na experiência de sofrimento narrada por esses filhos, que profundamente me tocaram ao longo de toda pesquisa, parece, então, ser analítica e politicamente necessário lembrar que essas experiências estão também inscritas na idealização de um modelo de família e parentesco que, como já apontava Bourdieu, tem recebido "do Estado os meios de existir e de subsistir" (BOURDIEU, 1996, p. 135). Neste sentido, vale se perguntar em que medida as políticas que visam a universalização do reconhecimento de paternidade não estão, a um só tempo, possibilitando agências e, 
paradoxalmente, reinstituindo o sofrimento associado à ausência do reconhecimento paterno.

\section{Referências Bibliográficas}

BOURDIEU, Pierre. Apêndice: O espírito de família. In: Razões práticas. Sobre a teoria da ação. Campinas: Papirus, 1996, p. 124-135.

BRASIL. Lei $n^{\circ}$ 6.515, de 26 de Dezembro de 1977. Lei do Divórcio. Regula os casos de dissolução da sociedade conjugal e do casamento, seus efeitos e respectivos processos, e dá outras providências. Disponível em:< http://www2.camara.gov.br/legin/fed/lei/19701979/lei-6515-26-dezembro-1977-366540-publicacaooriginal-1-pl.html>. Acesso em: 08 de fevereiro 2008.

BRASIL. Lei n 8.560, de 29 de Dezembro de 1992. Lei de Investigação de Paternidade. Regula a investigação de paternidade dos filhos havidos fora do casamento e dá outras providências. Disponível em :< http://www2.camara.gov.br/legin/fed/lei/1992/lei-8560-29dezembro-1992-349772-norma-pl.html> Acesso em: 04 de agosto de 2010.

CARSTEN, Janet. Introduction: cultures of relatedness. In: CARSTEN, Janet (Org). Cultures of relatedness. New Approaches to the study of kinship. Cambridge: Cambridge Univ. Press, 2000.

DUARTE, Luiz Fernando Dias e GOMES, Edlaine de Campos. Três famílias. Identidades e trajetórias transgeracionais nas classes populares. Rio de Janeiro : Editora da FGV, 2008.

FINAMORI, Sabrina. Os sentidos da paternidade: dos "pais desconhecidos" ao exame de DNA. Campinas (SP). 330f. Tese (Doutorado em Ciências Sociais - Área de Estudos de Gênero) - IFCH/UNICAMP, 2012.

FONSECA, Claudia. Caminhos da adoção. São Paulo: Cortez, 1995.

. Da circulação de crianças à adoção internacional: questões de pertencimento e posse. Cadernos Pagu, n' 26, p. 11-43, jan-jun, 2006.

GEFFRAY, Christian. Nem pai, nem mãe. Crítica do parentesco: o caso macua. Lisboa: Ndjira, 2000. (Tradução: Maria do Rosário Paiva Bolío).

HACKING, Ian. The social construction of what? Cambridge: Harvard University Press, 1999. 
LAMBEK, Michael. The cares of Alice Alder: recuperating kinship and history in Switzerland. In: CARSTEN, Janet (Org.). Ghosts of memory: essays on remembrance and relatedness. Malden: Blackwell, 2007.

MILLER, Daniel. How infants grow mothers in North London. Theory, Culture and Society, n.14: 67-88, 1997.

PINA CABRAL, João de e LIMA, Antónia Pedroso de. Como fazer uma história de família: um exercício de contextualização social. Etnográfica, v. 9, n. 2, p. 355-388, 2005.

SAHLINS, Marshall. What Kinship Is-And Is Not. Chicago: University of Chicago Press, 2012.

SCHNEIDER, David. American Kinship. Chicago: University of Chicago Press, 1980 [1968]. . A Critique of the Study of Kinship. Ann Arbor: University of Michigan Press, 1984.

SCOTT, Joan. The evidence of experience. Critical Inquiry. v. 17, n' 4 (Summer), p. 773-797, 1991.

SEGALEN, Martine. The shift in Kinship studies in France: the case of grandparenting. In: FRANKLIN, Sarah e MCKINON, Susan (Org.). Relative values. Reconfiguring kinship studies. Durham: Duke University Press, 2001.

SMITH, Barbara Herrnstein. Narrative Versions, Narrative Theories. Critical Inquiry, v.7, n. 1, p. 213-236 , Autumn, 1980. Published by: The University of Chicago Press Stable, 1980.

STRATHERN, Marilyn. Kinship, Law and the unexpected. Relatives are always a surprise. Cambridge: Cambridge Univ Press, 2005.

TRONTO, Joan C. Moral boundaries. A political argument for an ethic of care. London/ New York: Routledge, 1993.

WEBER, Florence. Lares de cuidado, linhas de sucessão: algumas indicações etnográficas na França, hoje. Mana, v. 12, n.2, p. 479-502, 2006. 
Recebido em: 20/09/2013 Aprovado em: 06/11/2013

Universidade do Estado de Santa Catarina - UDESC Centro de Ciências Humanas e da Educação - FAED

Revista PerCursos

Volume 14 - Número 27 - Ano 2013 revistapercursos@gmail.com 